\title{
O PARADIGMA DO PASTORADO FEMININO NA IGREJA EVANGÉLICA DA ATUALIDADE
}

\section{ARTIGO ORIGINAL}

SÁ, Danielle Mendonça de ${ }^{1}$, GHEDINI, Robson Maurício ${ }^{2}$

SÁ, Danielle Mendonça de. GHEDINI, Robson Maurício. O paradigma do pastorado feminino na igreja evangélica da atualidade. Revista Científica Multidisciplinar Núcleo do Conhecimento. Ano 06, Ed. 12, Vol. 07, pp. 159-173. Dezembro de 2021. ISSN: 2448-0959,

Link de

acesso: https://www.nucleodoconhecimento.com.br/teologia/paradigma-dopastorado

\section{RESUMO}

Atualmente, há igrejas que optam por limitar a contribuição da mulher no exercício de seu ministério em alguns setores eclesiásticos, ou mesmo, por silenciá-la. Portanto, essa pesquisa se pauta na seguinte questão: de que forma a análise do papel da mulher no contexto bíblico, auxilia na aceitação da legitimidade do pastorado feminino na igreja evangélica da atualidade? Assim, objetiva-se neste estudo proporcionar um novo horizonte na compreensão do tema da liderança eclesiástica feminina, de modo a contribuir com o solucionamento desta problemática e com a quebra de paradigmas, à luz da Bíblia Sagrada, descrevendo as principais dificuldades enfrentadas pela mulher no exercício ministerial, ao passo em que busca compreender o pensamento

${ }_{1}$ Possui Mestrado em Teologia em andamento na linha de pesquisa Releitura de Textos e Contextos Bíblicos pela FABAPAR, pós-graduação em Estudos Analíticos do Pentateuco pela FABAPAR (2021), pós-graduação em Teologia e Interpretação Bíblica pela FABAPAR (2020), graduação Bacharel em Informática pela UNESA (2006) e graduação Bacharel em Teologia pela UNICESUMAR, em fase de conclusão (2021). ORCID: https://orcid.org/0000-0003-0150-6313

2 Orientador. ORCID: https://orcid.org/0000-0002-6862-8799 
oriundo de aspectos do contexto social, político, histórico, econômico e religioso da época em que os textos bíblicos foram escritos. Para tanto, utilizou-se como pressuposto metodológico a pesquisa bibliográfica e a abordagem qualitativa de forma descritiva, pois, fez-se necessário apresentar elementos e fatos extraídos da história referentes a estes aspectos, visto que, a junção de todos, possibilitou traduzir o modo como os homens e as mulheres daquela época se portavam, pensavam e sentiam. Compreende-se, ainda, que esse pensamento impregnou a tradição da Igreja, ao longo dos séculos, no entanto, ressalta-se que a tradição cultural da época, não possui os mesmos elementos socioculturais da atualidade. Nesse sentido, são reunidas informações sobre as dificuldades enfrentadas pelas mulheres no campo social e religioso, a função feminina no judaísmo, sua participação no Cristianismo, desde o modo como Jesus as tratava; à participação delas na Igreja Primitiva, além de oferecer espaço de análise de textos bíblicos que lançam luz sobre a visão bíblica dos ministérios femininos, um relato sobre a história de Débora, uma pastora na prática, apesar de não ostentar o título, bem como, aborda-se sobre o ministério pastoral como um dom concedido por Deus. Conclui-se então que na atualidade conclama-se por mais mulheres destemidas, corajosas, fiéis a Deus, piedosas, obedientes, leais, pastoras de almas, como Débora, Miriã, Hulda entre outras. Afinal para homens e mulheres há um só Deus, uma só missão (a Dele), uma só visão e um só alvo, Jesus.

Palavras-chave: Bíblia, igreja, liderança, mulheres, tradição.

\section{INTRODUÇÃO}

A respeito do tema da liderança feminina na sociedade atual, caso o seguinte questionamento fosse direcionado a pessoas de diferentes gêneros: "Você aceitaria de bom grado ser liderado por uma capitã militar, caso fosse o seu oficial subordinado? Aceitaria ser o copiloto de um avião ciente de que ele é pilotado por uma mulher? Aceitaria se submeter às diretrizes de uma líder gestora de uma empresa?", possivelmente, a resposta de muitos, tanto homens quanto mulheres, seria: "Sim, desde que ela seja plenamente qualificada para a função". Entretanto, no ambiente eclesiástico, a ordenação de mulheres a cargos de liderança tem sido pauta de muitas discussões nos últimos tempos. 
A tradição eclesiástica, muitas vezes, proíbe que as mulheres preguem ou ensinem. A base teológica para essa teoria é fundamentada em instruções, como as paulinas, que ocorrem dentro de um contexto em que as mulheres geralmente não eram instruídas, em uma sociedade apegada a valores e costumes decorrentes da tradição judaica, e, também, gentílica, onde havia a necessidade do apóstolo resgatar e manter a ordem na Igreja, de modo a não escandalizar aos irmãos recém convertidos ao Cristianismo. A tradição judaica proibia que as mulheres ensinassem na sinagoga. A tradição grega, as impedia, quase que totalmente, de terem vida social, pois estavam afastadas dos lugares e dos acontecimentos públicos, inclusive, dos religiosos.

Ao longo dos séculos, a figura feminina tem sofrido com a repressão intelectual, ainda que silenciosa, e, por vezes, humilhações, o que tem desencadeado a luta feminina por seu espaço em um mundo dominado, por gerações inteiras, pela figura masculina. Fatores como, a desigualdade salarial, obstáculos invisíveis nas promoções, desrespeito e abuso de autoridade masculina, ainda tem sido a realidade de muitas mulheres na atualidade. Diante dessa dificuldade de entendimento, essa pesquisa justifica-se por reunir conceitos e fundamentos bíblicos que abordem o tema da liderança eclesiástica feminina, afinal, Deus não depende de julgamentos humanos para realizar a sua obra redentora. Na história da Igreja, Jesus conta com homens e mulheres como cooperadores da sua Missão dada à Igreja (BÍBLIA, 2011, 1 Coríntios 3.9).

Com o aumento crescente das denominações cristãs que aceitam a legitimidade do pastorado feminino e a multiplicação de igrejas plantadas por mulheres, muitos embates têm acontecido entre diferentes grupos do meio evangélico. Daqueles que defendem e crêem que mulheres podem ocupar posições de liderança pastoral eclesiástica, e dos que defendem e crêem que somente homens possuem a autorização Divina para ocupar tais posições. Há um contraponto a ser considerado que é de fundamental importância, saber o que a Bíblia diz a respeito desse assunto. Portanto, buscou-se reunir informações da literatura bíblica e judaico-cristã sobre o assunto, visando esclarecer a seguinte pergunta: de que forma a análise do papel da 
mulher no contexto bíblico, auxilia na aceitação da legitimidade do pastorado feminino, na igreja evangélica da atualidade?

A Bíblia é a inerrante e infalível Palavra de Deus (BÍBLIA, 2011, 2 Timóteo 3.16). Considerando que os homens inspirados por Deus viviam dentro de um contexto social, político, histórico, econômico e religioso, para extrair as verdades Bíblicas nela contidas, se faz primordial conhecer a cultura e a proposta original dos textos bíblicos antes de realizar a sua devida interpretação e, se tratando da cultura judaica, é necessário ter ainda mais cautela devido às suas particularidades literárias e poéticas, pois, se elementos estritamente ligados à cultura do povo judeu fossem preservados na contextualização dos textos, situações como, mulheres utilizando véu como prérequisito no culto a Deus, conforme escrito pelo apóstolo Paulo na Bíblia Sagrada (2011) em 1 Coríntios 11.1-16, seriam atualmente vivenciadas.

Assim, essa pesquisa objetiva contribuir com o esclarecimento do que a Bíblia ensina sobre o papel da mulher na Igreja de Cristo e o modo como Ele a torna participante da sua Missão, com elementos e fatos extraídos da história, de modo a proporcionar um novo horizonte na compreensão do tema da liderança eclesiástica feminina. Além disto, visa, também contribuir com o solucionamento desta problemática à luz da visão bíblica sobre o tema e, para isto, utilizou-se como pressuposto metodológico a pesquisa bibliográfica e a abordagem qualitativa de forma descritiva. $\mathrm{Na}$ coleta de informações para o levantamento dos dados e fatos, além da Bíblia Sagrada, este estudo contou com os seguintes autores: Curtis Allen, Branca Moreira Alves, Jacqueline Pitanguy, Simone Beauvoir, Russell Champlin, Arthur Cundall, Kathy Keller, Sandra Kochmann, Lucado, John MacArthur, Eugene Merril, Flávio Josefo, Charles Pfeiffer; Everett Harrison, Fani Averbuh Tesseler, Nicholas Thomas Wright, entre outros.

Esse artigo se aplica a mulheres que, assim como a autora, tem sofrido com a falta de aceitação e o preconceito de líderes que não reconhecem a autoridade Divina no exercício do ministério pastoral feminino e, também, a todos aqueles que são cooperadores e amantes da Missão de Deus e da sua Santa Palavra. Em sua estrutura, inicialmente, é abordado no tópico denominado "uma voz reprimida na 
sociedade", um relato sobre as principais dificuldades enfrentadas pelas mulheres no acesso à educação e sobre o modo como ela é vista pela sociedade no âmbito social e religioso. No segundo tópico, são reunidas informações sobre "a função da mulher no judaísmo", considerando, principalmente, o pensamento da Rabina Sandra Kochmann sobre $o$ assunto.

No terceiro, é abordada "a participação da mulher no cristianismo", subdividido em: "Jesus quebrou paradigmas humanos", que apresenta informações sobre o modo como Jesus tratou as autoridades religiosas de sua época, que invalidaram a Lei de Deus em detrimento às tradições humanas; "Jesus valorizou as mulheres", a partir dessa temática, explicita a maneira como Jesus se portou com as mulheres daquela época, valorizando-as e incluindo-as, sem acepção, contrariando, inclusive, tradições rabínicas, como a que o proibia de dirigir-se a elas publicamente; "Mulheres caladas na igreja", que analisa e oferece uma adequada interpretação de textos bíblicos polêmicos, como o de 1 Timóteo 2.11,12 e o de 1 Coríntios 14.34,35, para a devida compreensão da mensagem proposta; e o último subtópico, que reúne alguns dados relacionados à "participação da mulher na igreja primitiva", no contexto bíblico.

No quarto tópico, é relatada a história de "Débora, uma pastora na prática", que, apesar de não ostentar o título, detinha todos os atributos que o conferem, principalmente, o chamado de Deus, que a capacitou para liderar a sua nação, sem que isso ofuscasse o seu papel de boa esposa e de boa mãe, um verdadeiro exemplo a ser seguido por todos. Finalmente, o último tópico da discussão apresenta "o ministério pastoral como um dom concedido por Deus" e que, portanto, Ele o concede a quem quer e como quer, sem que haja distinção alguma, unicamente para a edificação da sua Igreja; finalizando com as considerações finais.

\section{UMA VOZ REPRIMIDA NA SOCIEDADE}

A liderança religiosa, por muitas gerações pertenceu à figura masculina. Para a Rabina Kochmann[3] (2005), no decorrer da história, a preferência no estudo da Bíblia era do homem, pois a mulher não tinha acesso a tantas informações como nos dias atuais. Sobre a figura feminina, no século IV a.C, na Grécia antiga, Xenofonte declara: 
"[...] que viva sob uma estreita vigilância, veja o menor número de coisas possível, ouça o menor número de coisas possível, faça o menor número de perguntas possível" (ALVES; PITANGUY, 1985, p. 12). Tais declarações refletiam o pensamento da época sobre o assunto e o modo como as mulheres eram reprimidas pela sociedade de dominação prioritariamente masculina. No Brasil, somente a partir do final do século XIX, a mulher passou a frequentar escolas, e mesmo assim, de forma tímida, pois, inicialmente, somente as escolas particulares eram destinadas às mulheres (TESSELER, 2009).

Sobre o modo como ela é vista na sociedade, Beauvoir (1970, p. 72) afirma em um texto escrito na década de 70 , que "o homem é definido como ser humano e a mulher é definida como fêmea. Quando ela se comporta como ser humano é acusada de imitar o macho". Em um texto mais recente, contendo o depoimento de Kathy Keller, esposa de um dos mais proeminentes pastores da atualidade, Tim Keller, com quem se casou e o acompanhou na liderança da West Hopewell Presbyterian Church na Virgínia por nove anos, ela declara:

\begin{abstract}
Em todos os lugares nos quais tenho ministrado desde então, sintome como uma mulher sem país. Em alguns deles, sou vista com suspeição, como uma 'louca feminista', porque encorajo mulheres a ensinar e a liderar, e eu mesma faço. Certa vez, no norte da Escócia, durante uma sessão de perguntas e respostas conduzidas pelo Tim após o culto de uma congregação da Free Church of Scotland (Igreja Livre da Escócia), eu entrei na conversa. Como normalmente fazíamos a sessão de perguntas e respostas juntos todo domingo em nossa casa, após o culto da noite, nunca liguei sobre expressar minha opinião. No entanto, todas as cabeças viraram para me olhar com incredulidade estampada em face, masculina e feminina. Foi como se o cachorro de repente tivesse falado (KELLER, 2019, p. 8).
\end{abstract}

O problema vivenciado por Keller em seu depoimento, infelizmente, ainda tem sido a triste realidade de muitas mulheres, seja no meio social ou religioso. Segundo Perrot (1992, p. 185), "da História, muitas vezes, a mulher é excluída". Segundo dados do Ministério da Economia, 43,8\% das mulheres ocupam cargos de gestão no Brasil, ou seja, elas ainda representam a minoria em cargos de mais alto escalão e, apesar de ocuparem cargos de liderança, sua remuneração média ainda é inferior à dos homens, 
em $69,8 \%$, para as mesmas ocupações de diretoria, chefia, supervisão, gerência, coordenação e direção (BRASIL, 2019).

\section{A FUNÇÃO DA MULHER NO JUDAÍSMO}

A função da mulher no judaísmo, de acordo com Kochmann (2005), diversificou conforme com o seu contexto sócio histórico e sofreu influências estrangeiras, principalmente a grega, que a impedia, quase que totalmente, de ter uma vida social, pois a afastava de lugares e de acontecimentos públicos, inclusive, religiosos. Segundo ela,

$\mathrm{Na}$ época bíblica, as mulheres dos Patriarcas eram as Matriarcas, mulheres ouvidas, respeitadas e admiradas. Havia mulheres profetisas e juízas. As mulheres estavam presentes no Monte Sinai no momento em que Deus firmou o Seu Pacto com o povo de Israel. Participavam ativamente das celebrações religiosas e sociais, dos atos políticos. Atuavam no plano econômico. Tinham voz, tanto no campo privado como no público. Com o decorrer do tempo e por força das influências estrangeiras, especialmente a grega, foram excluídas de toda atividade pública e passaram a ficar relegadas ao lar. Essa situação das práticas cotidianas daquela época foi expressa nas leis judaicas então estabelecidas e permanece a mesma até hoje (KOCHMANN, 2005, p. 35-36).

Em concordância, MacArthur (2019) afirma em seu relato sobre a posição feminina na época dos patriarcas da Bíblia, que

Os relatos bíblicos dos patriarcas sempre dão o destaque devido às suas mulheres. [...] Miriã, irmã de Moisés e de Arão, era tanto profetisa quanto compositora - e em Mq 6:4, o próprio Deus a honra, ao lado de seus irmãos, como uma das líderes da nação durante o Êxodo. Débora, também uma profetisa, era juíza em Israel antes da monarquia (Jz 4:4). [...] Em Provérbios, a sabedoria é personificada como uma mulher. A Igreja do Novo Testamento é igualmente representada por uma mulher, a noiva de Cristo (MACARTHUR, 2019, p. 16-17).

Entretanto, a religião pagã tendia à desvalorização da mulher. A mitologia grega e a romana tinham suas deusas, como Diana e Afrodite, servidas por prostitutas sagradas, uma prática declaradamente humilhante para a mulher (MACARTHUR, 2019). Com o passar do tempo, alguns elementos foram incorporados à tradição judaica e reunidos no Talmud, uma coletânea de livros sagrados judeus. Para 
Kochmann (2005, p. 37), "no período talmúdico", compreendido entre os séculos III e VI d.C., "época na qual foram estabelecidas as regras do dia a dia judaico, baseadas na interpretação e análise dos textos bíblicos pelos rabinos (exclusivamente homens)", a mulher encontra barreiras para frequentar o cenário público, porque essa concepção "recebe influência direta da antiga sociedade grega em que estava inserida. Nela, a mulher praticamente não tinha vida social, já que estava afastada dos lugares e acontecimentos públicos, entre eles, os religiosos". Segundo Judith Baskin,

Carol Meyers argumenta que, quando o trabalho agrícola e a gravidez, duas esferas nas quais as mulheres desempenhavam um papel ativo, eram centrais na sociedade bíblica, a vida social e religiosa no Israel antigo era relativamente igualitária. Quando o estado político e a monarquia emergiram, e a vida religiosa foi institucionalizada no culto ao templo e na burocracia sacerdotal (a partir do século $X$ a.C), no entanto, as mulheres foram cada vez mais excluídas da arena pública e perderam o acesso à autoridade comunitária (BASKIN, 2020, s.p.).

$\mathrm{Na}$ cultura judaica, foram inseridos certos costumes e hábitos considerados tão degradantes e humilhantes para as mulheres, que Sandra Kochmann afirma:

Começar cada dia escutando os homens dizerem 'Bendito sejas Tu, Eterno, nosso Deus, Rei do Universo que não me fizeste mulher' não é agradável para mulher alguma que, por sua vez, deve proferir com 'resignação' as palavras 'Bendito sejas Tu, Eterno, nosso Deus, Rei do Universo, que me fizeste segundo Tua vontade'. Essas bênçãos fazem parte da liturgia tradicional judaica dentro do conjunto de 'agradecimentos a Deus' conhecido como 'Bênçãos matinais' e que são recitadas toda manhã ao despertar. [...] Segundo o rabino contemporâneo Joel H. Kahan, essa bênção se originou do dito helênico popular, citado por Platão e Sócrates [...]. 'Ser homem e não mulher' era central em ambas as culturas, onde a mulher ocupava um lugar secundário, especialmente na vida pública (KOCHMANN, 2005, p. 36-37).

O rito acima mencionado foi incorporado à tradição judaica e a figura feminina foi inferiorizada em relação à masculina, classificada como um "ser humano de segunda categoria". Inclusive, na sociedade judaica, mulheres e crianças, não eram contadas nos censos e isto dificulta a determinação da sua soma populacional. Vaux (2004) afirma que, até mesmo o total mais baixo, de 2 Samuel 24.1-9 (BÍBLIA, 2011), é muito 
exagerado, pois, faltam documentos estatísticos, ou seja, apesar de, na Bíblia, haver algumas indicações numéricas, elas não ajudam muito.

A leitura da Torá de forma pública, é parte do aspecto da liturgia de culto da sinagoga, do qual as mulheres estariam isentas. Caso uma mulher se levantasse no lugar de um homem para realizar a leitura da Torá, por estar incluída entre os leitores da cerimônia, ao todo sete, isso implicaria que nenhum dos homens presentes seria capaz de cumprir tal obrigação, uma situação vergonhosa, para muitos judeus (KOCHMANN, 2005). Outros interpretam que a atitude seria considerada desonrosa somente nos casos em que a leitura fosse feita inteiramente por uma mulher (SHPERBER, 2003).

Kochmann (2005) argumenta que, considerando o fato de que, na atualidade, já é permitido à mulher judia assumir atribuições religiosas das quais anteriormente seria isenta, como acontece também em outros níveis da sociedade, muitas delas pleitearam o direito de estudar para se formarem rabinas e líderes comunitárias. Para ela, o conhecimento de antecedentes e de mutações da lei judaica, ajudaria a compreender o quanto ela é dinâmica e, consequentemente, possibilitaria uma maior aceitação dessa nova realidade.

\section{A PARTICIPAÇÃO FEMININA NO CRISTIANISMO}

Toda a Escritura Sagrada aponta para Jesus, pois Ele é o sujeito, o alvo e o cumprimento das profecias do Antigo Testamento (BíBLIA, 2011, Mateus 1.22; $2.6,15,17-18,23$; 3.3; 4.14-16). Segundo Keller (2019, p. 10), "Jesus confiou na inspiração do Antigo Testamento e prometeu a inspiração do Novo Testamento", através do Espírito Santo (BÍBLIA, 2011, João 14.26). Sobre a interpretação adequada dos textos bíblicos, Allen (2012) afirma que é preciso interpretá-los respeitando o contexto em que estão inseridos e à luz de Cristo, o cumpridor da Bíblia em sua totalidade, assumindo que Ele é o modelo de conduta para todo o cristão (BÍBLIA, 2011, 1 João 2.6), como diria Sheldon (2007), em seu livro intitulado Em seus passos o que faria Jesus? Sendo assim, há que se analisar o que Ele ensina sobre o papel da mulher em sua Igreja e de que modo Ele, também, a torna participante da sua 
Missão de salvação e resgate da humanidade. A seguir, são reunidas estas informações, de forma concisa.

\subsection{JESUS QUEBROU PARADIGMAS HUMANOS}

Durante o ministério terreno de Jesus, dentre as autoridades religiosas da época, destacava-se um grupo denominado "fariseus", homens respeitados pelos judeus como sendo profundos conhecedores das leis judaicas (JOSEFO, 2004). No entanto, eles haviam construído um sistema próprio de interpretação, que se tornou um conjunto de tradições e regras, muitas vezes, colocados acima das Escrituras Sagradas quando havia discordância entre elas, o que se tornou perigoso, pois eles valorizavam mais as tradições humanas do que a Palavra de Deus, conforme thes advertiu Jesus, em Marcos 7.13. Josefo (2004, p. 819) classifica-os como "[...] uma seita de homens que querem que os julguemos mais instruídos que os outros na religião, que eles são tão queridos de Deus, que Ele se Ihes comunica e dá-Ihes o conhecimento das coisas futuras".

Segundo Allen (2012, p. 54), em seu comentário sobre Mateus 12.1-8, "Jesus fala diretamente à arrogância da interpretação dos fariseus". Ele os acusou de não serem praticantes da Lei de Deus, apesar de serem conhecedores dela (BÍBLIA, 2011, Mateus 23.23-28). Para Merril (1987, p. 412), “Jesus, de fato, afirmou que o juízo imposto sobre os fariseus seria maior do que o que recaiu sobre Nínive. [...] os fariseus não se arrependeram com a pregação daquele que era maior do que Jonas (LC 11.32)". Jesus rejeitou o conjunto de instruções impostos pela tradição judaica, que eram contrários ao verdadeiro propósito Divino, de salvar o homem pecador (BÍBLIA, 2011, Mateus 18.11), entre eles, os que tentaram impedi-lo de realizar milagres no sábado, o dia de descanso dos judeus, segundo a Lei de Deus (BíBLIA, 2011, Êxodo 34.21).

Logo após curar um homem que possuía uma das suas mãos deformadas, dentro da sinagoga local (BÍBLIA, 2011, Mateus 12.9-10), Jesus responde aos fariseus que o questionaram quanto à licitude da sua ação, dizendo: “[...] Qual dentre vós será o homem que tendo uma ovelha, se num sábado ela cair numa cova, não lançará mão 
dela, e a levantará? Pois, quanto mais vale um homem do que uma ovelha? É, por consequência, lícito fazer bem nos sábados" (BÍBLIA, 2011, Mateus 12.11-12), o que significa que a prática do bem deve ser diária, não importando o dia da semana. Jesus é o Senhor, "até mesmo do sábado" (BÍBLIA, 2011, Mateus 12.8). Ele quebrou paradigmas humanos e estabeleceu o Reino de Deus (BÍBLIA, 2011, João 14.6), segundo a sua boa, perfeita e agradável vontade (BÍBLIA, 2011, Romanos 12.2).

\subsection{JESUS VALORIZOU AS MULHERES}

Conforme acima mencionado, durante o ministério terreno de Jesus, a figura feminina era pouco valorizada pela sociedade da época. No entanto, o Mestre não fez distinção alguma. Apesar de ter selecionado doze apóstolos para si, o colegiado apostólico não era composto apenas por eles. Ele também possuía muitos outros discípulos, entre os quais havia, também, mulheres, "uma prática desconhecida entre os rabinos de sua época" (BÍBLIA, 2011, p. 1639), e, algumas delas, o auxiliavam com a doação de recursos financeiros próprios (BÍBLIA, 2011, Lucas 8.1-3). Elas exerceram suporte e papel fundamental no ministério de Jesus. O Mestre as incentivou ao discipulado, elevando, inclusive, a sua importância à do serviço doméstico (BÍBLIA, 2011, Lucas 10.38-42). Nos relatos sobre os discípulos de Jesus, a Bíblia cita mais sobre Maria Madalena, Marta, Maria, mãe de Tiago, e Salomé, do que sobre Natanael ou Matias. Além disso, Jesus também possuía muitos discípulos anônimos e cooperadores amados (BÍBLIA, 2011, Lucas 10.1) e, nos dias de hoje, a lgreja do Senhor Jesus está espalhada por toda parte do mundo, em um número incontável de discípulos (BÍBLIA, 2011, Mateus 28.18-20; Romanos 12.4-5).

Jesus quebrou paradigmas humanos, ao se reportar à mulher Samaritana no poço de Jacó (BÍBLIA, 2011, João 4.9), contrariando as críticas da sociedade e, até mesmo, a incompreensão dos seus próprios discípulos (BÍBLIA, 2011, João 4.27) e, ainda, a transformou em uma missionária do seu povo (BÍBLIA, 2011, João 4.28-30). Segundo A Bíblia da Mulher. "Culturalmente, judeus e samaritanos não se associavam uns com os outros. Além disso, era considerado impróprio para um rabino conversar com uma mulher em público. A consideração de Cristo por essa mulher era, portanto, revolucionária." (BÍBLIA, 2011, p. 1639). Ele tratou com dignidade mulheres que eram 
marginalizadas pela sociedade da época (BÍBLIA, 2011, Mateus 9.20-22; Lucas 7.3750; João 4.7-27). Durante o ministério de Jesus, as mulheres não só foram valorizadas, como também comissionadas, juntamente com os homens a serem "luz do mundo" (BíBLIA, 2011, Mateus 5.14-16) e capacitadas pelo Espírito Santo a testemunharem da salvação de Deus até os confins da Terra (BíBLIA, 2011, Atos 1.8).

MacArthur (2019, p. 190) afirma que "Cristo encorajou homens e mulheres a tomarem sobre eles seu jugo e a aprender com Ele. Essa também é outra prova de como as mulheres são honradas nas Escrituras". Foram elas, também, as primeiras a testemunharem a sua ressurreição e a receberem a ordem de compartilhar com os demais a notícia de que Ele está vivo (BÍBLIA, 2011, Marcos 16.7; João 20.15-18). É possível afirmar que o vezo cultural de sua época, em Pedro e nos demais discípulos de Jesus, foi preponderante para que eles duvidassem do relato das mulheres que haviam testemunhado a ressurreição de Jesus (BÍBLIA, 2011, Marcos 16.9-11; Lucas 24.9-12), pois, conforme acima mencionado, segundo a tradição judaica antiga, o testemunho público delas não era confiável.

Ele também afirma que Maria Madalena, discípula de Jesus, "desponta como uma das mulheres mais importantes do Novo Testamento" (MACARTHUR, 2019, p. 183). A respeito do seu passado, os evangelhos a descrevem como uma mulher que havia sido liberta de uma possessão demoníaca (BÍBLIA, 2011, Lucas 8.2; Marcos 16.9). Ele argumenta que "sem revelar nenhum detalhe degradante do passado dessa mulher, eles registram a sua escravidão a demônios de modo a exaltar o poder generoso de Cristo" (MACARTHUR, 2019, p. 190), ou seja, de escrava de demônios à fiel seguidora de Jesus Cristo, ela "passou a fazer parte do círculo íntimo de discípulos que viajavam com Jesus em suas longas jornadas" (MACARTHUR, 2019, p. 189). Segundo ele, ela, também, era uma das mulheres que ajudaram Jesus e seus discípulos com doações financeiras. De acordo com Lucado (2018, p. 213): “Depois do Senhor Jesus ter curado Maria, ela também se tornou uma devotada seguidora. Hipólito de Roma, um teólogo do século III, iria mais tarde chamá-la de "a Apóstola dos Apóstolos". Sua devoção, inclusive, fez com que ela permanecesse em Jerusalém durante a crucificação de Jesus (BÍBLIA, 2011, João 19.25). 
Em João 20.1-17, uma atitude de Maria chama a atenção. Após ter visto Jesus ressurreto, sua reação, possivelmente, foi de abraçá-Lo fortemente para não larga-Lo, ao ponto Dele declarar no versículo 17: "Não me detenhas". Sobre esta expressão, Champlin (1982, p. 636) argumenta que "o original grego é "aptomai", [...] este vocábulo pode ter o sentido de manusear ou deter, indicando algo mais do que o mero toque de algum objeto. [...] Mui provavelmente Maria Madalena se atirou aos pés do Senhor Jesus, e se agarrava a eles". Em concordância MacArthur (2019, p. 196) afirma que "Maria de um modo muito diferente não quis largar Jesus. Por isso Jesus Ihe conferiu uma honra inigualável, permitindo que ela fosse a primeira a vê-lo e ouvilo depois da sua ressurreição", tamanha era a sua devoção a Ele. Ela verdadeiramente o reconhecia como sendo o Filho de Deus.

\subsection{MULHERES CALADAS NA IGREJA}

Em 1 Timóteo 2.11,12, o apóstolo Paulo escreveu: "A mulher aprenda em silêncio com toda a submissão. Não permito que a mulher ensine, nem que tenha autoridade sobre o homem. Esteja, porém, em silêncio". No entanto, é possível perceber claramente que, segundo a Bíblia (2011), as mulheres não são proibidas por Deus, de falar em público. Segundo Kathy Keller,

[...] há vários exemplos no Novo Testamento de mulheres sendo elogiadas, e não condenadas, por falarem em público. Mulheres profetizam em 1Coríntios 11:5 (observe que, em 1Coríntios 12:28, o dom de profecia é considerado superior ao dom de ensino); Priscila e Áquila explicam o evangelho a um homem (Apolo) em Atos 18:26 e, em Romanos 16:3, Paulo se refere à Priscila como uma 'colaboradora' (synergos), designação também aplicada à Evódia e Síntique em Filipenses 4:3, mulheres que participaram do trabalho de evangelismo ao lado de Paulo. Também há no Antigo Testamento exemplos de mulheres líderes e profetas, como Miriã, Débora e Hulda [...] (KELLER, 2019, p. 25-26).

Logo, para Keller (2019), no texto acima mencionado, e, também, no texto de 1 Coríntios 14.34,35, que diz: "As mulheres estejam caladas nas igrejas, porque thes não é permitido falar; mas estejam sujeitas, como também ordena a lei. E, se querem aprender alguma coisa, interroguem em casa a seus próprios maridos; porque é indecente que as mulheres falem na igreja", Paulo se refere à ordem no culto, em 
continuidade ao que já vinha abordando desde o capítulo 11, ao ensinar que homens e mulheres deveriam manter os seus papéis conforme o ordenado por Deus, sendo o ato de cobrir a cabeça ao prestar culto a Ele, em 1 Coríntios 11.1-16, um sinal cultural relacionado à mulher. Ela afirma que "a Igreja Primitiva foi ensinada a orientar seu culto de acordo com o modelo de culto da sinagoga judaica" (KELLER, 2019, p. 28), no entanto, para ela, as mulheres não eram proibidas de exercerem seus dons publicamente, pois o apóstolo não estaria condenando esta conduta e, sim, regulandoa.

Entretanto, Champlin (1982) afirma que o apóstolo Paulo reconhecia a proibição absoluta às mulheres de participarem de qualquer modo, ativa e oralmente, nos cultos públicos, mas, apesar disso, tais proibições refletem meramente a atitude da época, a prática de um costume judaico antigo empregado nas sinagogas, pois o Novo Testamento não foi escrito em um vácuo. Logo, é natural que alguns ensinamentos de natureza estritamente "local e cultural" tenham sido incluídos, mas eles não podem ser obrigatórios para todos os lugares e épocas.

Casos notáveis de mulheres crentes, que foram mestras, profetisas e elementos de autoridade, são chamados de 'atos extraordinários de Deus', por Calvino, o que não perturbaria a ordem normal da Igreja. Mas essa ordem 'normal', conforme ensinado neste texto, na realidade só se aplica bem ao antigo judaísmo, e não à igreja moderna, onde os preconceitos contra as mulheres tem desaparecido grandemente, e onde uma atitude mais realista é mantida (CHAMPLIN, 1982, p. 304).

Sendo assim, a proibição expressa no texto bíblico não implica que às mulheres sejam negadas posições administrativas na Igreja Evangélica da atualidade. Champlin (1982) considera que tanto no texto de 1 Timóteo 2, quanto no de 1 Coríntios 14.34,35, é possível que a ordem dada às mulheres tenha sido direcionada à igreja local, levando em consideração situações pontuais que envolvessem mulheres que desonravam a igreja e a liderança, não sendo assim, normativa para todas as mulheres da Igreja do Senhor Jesus. Ele também considera que, na tradição judaica, uma mulher decente nunca deveria ser vista em público, exceto em alguns feriados especiais, o que não é conveniente na igreja Evangélica da atualidade. Portanto, dentro dessas condições sociais, quão fora de lugar seria permitir que as mulheres 
participassem oralmente dos cultos públicos. Nas sinagogas judaicas esse procedimento seria considerado um escândalo. Porém, tal instrução é classificada por ele como um sinal cultural, bem como a acima mencionada, referente ao uso véu pelas mulheres no culto público, em 1 Coríntios 11.1-16 (BÍBLIA, 2011). Logo, tal tradição não se aplica à Igreja Evangélica atual.

Sobre a instrução dada à mulher de que ela não ensine ao homem, com base na ordem da criação, expressa no texto de Gênesis 3.1-6, Russell Champlin argumenta que

[...] Aquela primeira ocasião em que a mulher resolveu 'ensinar' ao homem, ou exercer influência sobre ele, foi horrivelmente fatal. [...] Por meio desse exemplo tornar-se-ia óbvio que a mulher não é digna de gozar de igualdade com o homem. Antes, a ordem natural das coisas é que a mulher sempre se ponha sob a autoridade masculina, pois isso evitará maiores desastres. Esse é o raciocínio por detrás desse versículo, o qual concorda perfeitamente com a atitude judaica acerca das mulheres. [...] Dessas maneiras é que vários intérpretes têm procurado subestimar o papel de Adão em toda a questão, fazendo Eva parecer muito pior do que realmente ela foi, o que é típico da mentalidade judaica. Os judeus chamavam Eva de 'mãe de toda a iniquidade e pecado' (Talmude Hieros. Sabbat. fol 5:2; Sohar em Gênesis, fol. 27:3) [...] (CHAMPLIN, 1982, p. 305).

Em relação ao texto de 1 Timóteo 2.11,12, o Bibliatodo (2020) considera o fato de que a igreja de Éfeso teria problemas com falsos mestres e, como às mulheres judias era negado o direito ao aprendizado de forma similar ao que era oferecido aos homens, elas estariam despreparadas para lidar com estas questões, tornando-se alvos fáceis desses mestres enganadores, por estarem inaptas a discernirem a verdade. $E$ ainda comenta que

[...] Assim como Eva tinha sido enganada no jardim do Éden, assim as mulheres na igreja estavam sendo enganadas por falsos professores. E assim como Adão foi o primeiro ser humano criado Por Deus, assim os homens na igreja de Éfeso seriam os primeiros em falar e ensinar, porque tinham mais experiência. [...] Outros eruditos, entretanto, sustentam que os róis que Paulo destaca são os intuitos de Deus para sua ordem criada (BIBLIATODO, 2020, s.p.). 
Entretanto, assim como, tanto Adão, quanto Eva, encontraram a justiça de Deus, ambos, experimentaram, também, da sua graça (BÍBLIA, 2011, Romanos 5.18-19). Para Russell Champlin,

O autor procura justificar suas regras severas e restringidoras acerca das mulheres à base do fato que é a ordem da criação [...]. Para o autor sagrado, a inferioridade de Eva, o fato que ela veio à existência depois de Adão, significa que todas as mulheres devem ocupar posição de inferioridade. Mas esse conceito foi abolido em Gl 3.28, pois Cristo é o fim de tudo isso (CHAMPLIN, 1982, p. 305).

Em contrapartida, Wright (2020) afirma que, nesse texto, em momento algum, Paulo condena a ordenação de mulheres ao ministério pastoral. Para ele, o foco é justamente o contrário, de que elas não deveriam ser impedidas de estudar e de aprender, uma vez que isto não implicaria que se tornassem mandonas, como as mulheres sacerdotisas do templo de Artêmis, em Éfeso (pois, segundo ele, há indícios de que Timóteo estivesse nessa cidade quando recebeu essa carta, a ele direcionada. Ele afirma que no versículo 12, é isso que Paulo nega ao usar a expressão "nem exerça autoridade de homem"). Sendo assim, para o apóstolo, as mulheres deveriam ser encorajadas a estudarem e a aprenderem a assumir posições de liderança, pois, Adão pecou deliberadamente com conhecimento de causa, ele havia recebido a ordem diretamente de Deus. Contudo, Eva foi enganada. Logo, as mulheres deveriam ser incentivadas ao estudo para não serem confundidas.

Ele argumenta que a maternidade, para o apóstolo, não era vista como maldição, como um sinal do desprezo de Deus, como muitos judeus viam na época, e, sim, como uma contribuição com a criação de Deus. Segundo ele, o autor do texto bíblico pretendia contribuir com a edificação da Igreja de Cristo, para que, em unidade, pudessem servir a Deus.

$\mathrm{Na}$ interpretação dos textos acima analisados, essa pesquisa defende a teoria de que o apóstolo Paulo, embora fosse um apoiador do ministério feminino, a ser exposto no tópico a seguir, devido ao modelo de culto prestado assemelhar-se ao das sinagogas judaicas e ao fato das igrejas locais às quais ele se dirigiu em suas cartas possuírem, em sua membresia, muitos judeus e, também, gregos convertidos ao Cristianismo, 
ainda, muito arraigados, em suas tradições culturais, ele precisou ser enérgico e cauteloso em suas ações relacionadas ao papel desempenhado pela mulher, com o intuito de promover a ordem no culto e, principalmente, a unidade da Igreja, visto que a liderança feminina seria um assunto que escandalizaria aos irmãos recémconvertidos à fé cristã, o que justificaria tais proibições, conforme acima sustentado por Champlin (1982). No entanto, por serem oriundas de um costume cultural, elas não se aplicam à igreja evangélica atual.

Entre os que são contrários à ordenação pastoral feminina, há quem diga que as mulheres ordenadas ao pastorado hão de dar conta a Deus por exercerem suas funções ministeriais, o que, segundo crêem, é "desautorizado por Deus". Porém, não estaria contrariando ao próprio Deus aquele que reprime, humilha, e, até mesmo, sufoca, o ministério de uma mulher eleita por Ele ao exercício do ministério pastoral, com atributos que a qualifiquem, o que inclui um caráter ilibado perante Deus e os homens? (BÍBLIA, 2011, 1Timóteo 2.15). Em outras palavras, é como se Deus elegesse e capacitasse a mulher ao pastorado e este, com base em elementos da tradição cultural, conforme acima mencionado, dissesse: "Não posso aceitar, pois é uma situação que contraria a tradição socioeconômica e religiosa da época em que os textos bíblicos foram escritos".

É como se, mais uma vez, a Igreja vivenciasse situação semelhante à do apóstolo Pedro, em Atos 10, quando Deus the disse "Não faças tu comum ao que Deus purificou" (BÍBLIA, 2011, Atos 10.15), referindo-se à evangelização dos gentios, contudo, apresentando, na visão, animais considerados impuros para os judeus, segundo a Lei de Deus, em Levítico 11. Embora em contextos diferentes, o entendimento também se aplica ao tema, pois o apóstolo, por diversas vezes, insiste em sua convicção baseada em tradições humanas, opondo-se à vontade de Deus de alcançar também ao povo gentio, mas, por meio da revelação de Deus, ele reconhece que Jesus Cristo morreu por todos, sem distinção alguma (BÍBLIA, 2011, Gálatas 3.28), e, então, declara: "[...] Reconheço, por verdade, que Deus não faz acepção de pessoas." (BíBLIA, 2011, Atos 10.34). De igual modo, não se deve tentar limitar o agir de Deus, impondo-Ihe elementos próprios das tradições humanas. 
Assim como nos tempos bíblicos, Deus tem escolhido mulheres revestidas pelo Espírito Santo, capacitadas para liderar e pastorear vidas para o seu Reino, o que, apesar de ir na contramão do contexto sociocultural da época em que os textos bíblicos foram escritos, não possui aspectos semelhantes na atualidade. Para Deus, o importante é que seus filhos o sirvam em obediência, fé e amor, atendendo ao chamado ministerial que Ele os outorgou. Do mesmo modo como procediam os fariseus dantes mencionados, na atualidade, a vontade e a eleição Divina são postas em xeque devido à cosmovisão daqueles que, insistentemente, decidem aplicar à realidade cristã elementos próprios da cultura local. Contrariando a tradição da época, Jesus valorizou as mulheres, permitiu que elas aprendessem e que fossem constituídas cooperadoras da Missão de Deus, assim como os homens.

\subsection{A PARTICIPAÇÃO DA MULHER NA IGREJA PRIMITIVA}

As mulheres tinham participação ativa no contexto bíblico. O estabelecimento da igreja de Filipos envolveu mulheres (como Lídia, em Atos 16.11-15, 40 (BÍBLIA, 2011)) e elas também estavam envolvidas na proclamação do Evangelho em Beréia (BÍBLIA, 2011, Atos 17.12), e, juntamente, com os homens, foram comissionadas a proclamar as boas novas da salvação de Deus (BÍBLIA, 2011, Mateus 28.18-20) para servirem a Deus e ensinarem à humanidade a sua mensagem (BÍBLIA, 2011, Atos 18.24-26; Romanos 16.1-7). A Igreja primitiva se reunia nos lares (BÍBLIA, 2011, Romanos 16.35; 1 Coríntios 16.19; Colossenses 4.15; Filemon 1.2), e as mulheres cooperavam, de forma ativa, com o discipulado. A igreja que se reunia nos lares era "menos igreja"? Tupan Júnior (2017, p. 18), afirma que "Igreja não é estrutura, não é templo, não é instituição, mas são pessoas convertidas ao Senhor Jesus". Para Champlin (1982, p. 160) "a maior parte das comunidades cristãs da era apostólica se reunia em casas, provavelmente por razões financeiras".

Conforme acima mencionado, Paulo saúda Ninfa e à igreja que está em sua casa (BÍBLIA, 2011, Colossenses 4.15). Em momento algum ele cita, por exemplo, "ao presbítero" ou "ao apóstolo" que está na casa de Ninfa, mas se refere diretamente a ela, de modo que é possível que ela mesma fosse líder da igreja que se reunia em sua casa. Em sua saudação aos Romanos, ele cita: 
Recomendo-Ihes nossa irmã Febe, serva da igreja em Cencréia. Peço que a recebam no Senhor, de maneira digna dos santos, [...] pois tem sido de grande auxílio para muita gente, inclusive para mim. Saúdem Priscila e Áquila, meus colaboradores em Cristo Jesus. [...] Saúdem também a igreja que se reúne na casa deles. [...] Saúdem Maria, que trabalhou arduamente por vocês (BÍBLIA, 2011, Rm 16.1-7).

É possível notar que em diversos momentos o apóstolo dirige palavras elogiosas ao exercício do ministério feminino. Noutros, como o ocorrido em 1 Timoteo 2, acima analisado, segundo Champlin (1982), o apóstolo precisou ser duro, para preservar a ordem no culto, sem escandalizar aos irmãos judeus e gentios convertidos ao cristianismo, muitos, ainda arraigados em suas tradições culturais. Então, em que momento as Escrituras afirmam que a mulher não deve exercer o ministério pastoral e receber a ordenação, ou seja, o "reconhecimento do dom"? - Nenhum. Apesar do apóstolo Paulo, inspirado por Deus, comparar o amor do marido à sua esposa ao de Cristo à sua Igreja (BÍBLIA, 2011, Efésios 5.25-26) e fazer o mesmo em relação à sujeição: "Vós, mulheres, sujeitai-vos a vosso marido, como ao Senhor; porque o marido é a cabeça da mulher, como também Cristo é a cabeça da Igreja, sendo ele próprio o salvador do corpo" (BÍBLIA, 2011, Efésios 5.22-23), a liderança eclesiástica por uma mulher não ofusca, e nem muda, o seu papel de mãe e esposa e de submissão em relação ao seu marido. A dominação do marido sobre a esposa é Bíblica (BÍBLIA, 2011, Gênesis 3.16), mas a dominação de toda a classe masculina sobre a feminina, ou seja, de todos os homens de uma sociedade à todas as mulheres, é um sinal cultural, conforme acima mencionado.

A Bíblia cita uma mulher que foi chamada por Deus para pastorear toda uma nação. Ela era líder, mas era mulher de Lapidote, ela julgava a causa do povo, mas era mulher de Lapidote, ela era ministra da Palavra, mas era mulher de Lapidote, ela era profetiza, mas era mulher de Lapidote, ela era valente de guerra, mas era mulher de Lapidote. Em nenhum momento, a Bíblia apresenta Lapidote como líder ou com alguma atribuição que, talvez, possuísse. Ela cita apenas que esta mulher chamada, eleita, pelo próprio Deus para ser líder, era mulher de Lapidote. Segundo Cundall (1986, p. 81), "Nada se sabe de Lapidote, marido de Débora, a não ser a mera menção de seu nome, que não foi o único a ficar apagado, visto que o próprio Baraque desempenhou papel secundário na peleja. Ele recebeu coragem e inspiração pela presença desta 
grande e talentosa mulher". Débora era líder governamental, militar e espiritual de sua nação (BÍBLIA, 2011, Juízes 4.4,5), contudo era referência de boa mãe e boa esposa para o "desconhecido" Lapidote.

Quando Deus elege ao ministério, Ele, também, capacita. Quando capacita, também, ensina. Foi Ele quem ensinou Débora a ter todas estas atribuições de liderança e governo e continuar sendo boa esposa e boa mãe, ao ponto de ser referência para toda uma nação (BÍBLIA, 2011, Juízes 5.7). O próprio Deus colocava as palavras certas, no momento certo e na medida certa nos lábios de Débora, e tudo que ela precisa fazer era obedecê-Lo e continuar sendo líder de Israel e mulher de Lapidote (BÍBLIA, 2011, Juízes 4-5).

\section{DÉBORA, UMA PASTORA NA PRÁTICA}

Débora foi uma líder do povo de Israel que viveu em um tempo em que os homens negligenciavam a Deus. Calvino reconheceu a liderança e o governo de Débora e atribuiu ao que ele chamou de "Atos extraordinários feitos por Deus" (CHAMPLIN, 1982, p. 304). Os governantes daquela época eram os juízes (MERRIL, 1987). Estes juízes, sob a ação e o governo do próprio Deus, praticavam atos heroicos em prol da nação. Deus estabeleceu juízes para governar o seu povo, pois "sob a liderança de Josué realizou-se a fase inicial da conquista da terra. A terra foi dividida entre as tribos, mas era necessário que os israelitas ocupassem o território que lhes fora destinado" (PFEIFFER; HARRISON, 1985, p. 42). Reis só passaram a existir anos depois, sendo o primeiro deles Saul (BÍBLIA, 2011, 1 Samuel 8).

Na época dos juízes não havia Rei sobre o povo, mas Deus os constituiu, para que os liderassem, julgassem a causa de Israel e os conduzissem, dando sequência à liderança de Moisés e a de Josué. Portanto, Débora por ser juíza em Israel, era também governante daquela nação, tanto civil (julgava a causa do povo, Juízes 4.4 (BÍBLIA, 2011)), quanto militar (proferiu estratégias de guerra, Juízes 4.6-7 (BÍBLIA, 2011)), como espiritual (recebia o direcionamento de Deus e delegava as suas ordens ao povo de Israel, Juízes 4.4-7 (BÍBLIA, 2011)). Havia um propósito Divino ao designar Débora a liderar seu povo, função de extrema responsabilidade e autoridade, 
enquanto este sofria com a opressão de Jabim, Rei de Canaã. "Essas condições caóticas existiam porque Israel tinha adotado novos deuses e estava, portanto, experimentando o juízo divino. Então, Deus levantou Débora, que arregimentou homens dentre todas as tribos e alcançou uma poderosa vitória no Quisom e em Zaananin" (MERRIL, 1987, p. 170).

Também havia um outro aspecto decisivo e primordial, ela estava disponível e, com fé em Deus e coragem, obedeceu ao seu chamado (BÍBLIA, 2011, Juízes 5.7). Merril (1987, p. 170) afirma que "após o triunfo de Débora, a terra descansou por quarenta anos". Inspirada por Deus, ela apresentou à Baraque as estratégias de guerra e os animou ao combate: "Baraque e o resto dos israelitas, espantados com a multidão dos inimigos, intentaram retirar-se e afastar-se [...]. Mas Débora os deteve e ordenou-lhes que combatessem naquele mesmo dia sem temer, porque a vitória dependia de Deus, e deviam confiar no seu auxílio" (JOSEFO, 2004, p. 227).

A covardia inicial de Baraque em liderar o exército na situação difícil em que se encontrava a nação e a ousadia e o destemor de Débora em liderar toda uma nação, evidenciam que Deus atua na vida daquele servo ou serva que se coloca à sua inteira disposição, independente do seu gênero (mais tarde, Débora cantaria este canto profético: "Então [...] fez-me o Senhor dominar sobre os valentes" (BÍBLIA, 2011, Juízes 5.13), referindo-se aos valentes de guerra, em notória participação como líder, juntamente com Baraque). Cundall (1986, p. 23) afirma que eles partilhavam a liderança da nação: "[...] Débora, com Baraque, como apoio (Jz 4,5), [...]”. Contudo, em Hebreus 11.35 (BÍBLIA, 2011), ela não é citada, apenas Baraque, a figura masculina, apesar da liderança comprovadamente exercida com autoridade civil e espiritual concedidas por Deus, honradez, destaque e coragem. A possível explicação tem por base a cultura predominante da época, que desqualificava a mulher ao exercício de tais posições, conforme acima mencionado.

Além disso, é totalmente compreensível que, embora Débora detivesse todas as atribuições de uma "pastora", o texto não a apresente como tal, de forma explícita, e, sim, como juíza e profetiza, pois, a ideia de "pastorado" vinculada à condução de pessoas, só foi mencionada, tempos depois, nos Livros de Ezequiel e de Jeremias 
(BÍBLIA, 2011, Ezequiel 34; Jeremias 3.15-17). Anteriormente, ela estava associada unicamente à Deus (BÍBLIA, 2011, Gênesis 49.24; Salmo 23.1). Deste modo, descarta-se a possibilidade do escritor do Livro de Juízes, referenciá-la como tal, embora ela apresente todas as características de uma pastora ordenada por Deus. O mais próximo desse vocábulo no Antigo Testamento, considerando suas atribuições, era o termo "sacerdote".

Segundo Cundall (1986, p. 18), "o sumo sacerdote, em virtude de sua posição no santuário central, poderia ser considerado um juiz visto que o santuário era o lugar tradicional para o acerto de disputas, e era também o lugar procurado para se obter a benção de Deus, antes de uma campanha militar". No entanto, esta ocupação estava em descrédito, na época, devido ao despreparo e a falta de seriedade dos sacerdotes de então (BÍBLIA, 2011, Juízes 17-18). Porém, em meio ao pecado e à idolatria, Débora permaneceu fiel a Deus e à Torá. Mulher sábia e temente a Deus, muitos se aglomeravam ao seu redor para aconselhar-se e pedir-Ihe ajuda. Ela, então, julgava debaixo de uma palmeira, ao ar livre, ou seja, onde todos pudessem ouvi-la e observála, e advertia-os ao arrependimento de pecados (BíBLIA, 2011, Juízes 4.5).

Segundo Cundall (1986), o próprio Baraque reconheceu o governo e a liderança proeminentes em Débora. Sendo assim, embora tenha sido qualificada como "juíza" e "profetisa", sua atitude foi de uma verdadeira "pastora" do rebanho de Deus, e isto fica evidente no modo como ela transmitia a Mensagem divina de salvação ao povo de Israel, no caráter profético do seu ministério, no discernimento espiritual, na sensibilidade à voz de Deus, na sua postura de liderança e integridade que eram tão nobres e inspiradores, ao ponto de ser considerada "mãe de todo Israel" (BÍBLIA, 2011, Juízes 4,5), com uma conduta, indiscutivelmente, exemplar.

\section{O MINISTÉRIO PASTORAL COMO UM DOM CONCEDIDO POR DEUS}

O apóstolo Pedro, em 1 Pedro 4.10-11, inspirado por Deus, escreveu à Igreja de Cristo, a orientação de que cada um deve administrar o dom que recebeu, como bons despenseiros da multiforme Graça de Deus. Ele menciona os seguintes dons 
espirituais: os "dons da fala ("se alguém falar")", que incluem "apostolado, profecia, discernimento de espíritos, ensino, evangelismo e exortação" e os "dons de serviços ("se alguém administrar")", que consistem em "liderança, fé, administração, ajuda e celibato" (BÍBLIA, 2011, p. 1979-1980). No texto bíblico acima informado, ele instrui que cada cristão deve aplicar seus dons espirituais ao serviço ao próximo, para a edificação da igreja e para glorificar a Deus. Em sua declaração, não há distinção quanto ao gênero, masculino e feminino, raça e classe social, pois ele reconhece que Deus não faz acepção ao distribuir os seus dons espirituais. MacArthur (2019, p. 15) afirma que "desde o primeiro capítulo da Bíblia, somos ensinados que a mulher, assim como o homem, é portadora do selo da própria imagem de Deus (Gn 1:27; 5:1-2)”, ou seja, Deus deseja se relacionar igualmente com todos.

Em 1 Coríntios 12.7, o apóstolo Paulo diz que "a manifestação do Espírito é dada para o que for útil". Isto significa que é Deus quem escolhe, designa e qualifica um cristão ao exercício ministerial dentro do Corpo de Cristo, sem que haja distinção alguma, para edificação da Igreja de Cristo, crescimento, maturidade e unidade, pois uma igreja madura não é conduzida por todo "vento" de doutrina (BÍBLIA, 2011, Efésios 4.12-13). Sobre o termo "pastor", do Grego "poimén”, segundo A Bíblia da Mulher,

Davi é apresentado como um pastor cuidando do rebanho de seu pai. No mundo antigo o termo "pastor" costumava ser usado como metáfora para governante. Tanto no Antigo Testamento quanto no Novo Testamento, o povo de Deus é descrito, por analogia, como um rebanho, enquanto os representantes de Deus são chamados de pastores (2Sm 5.2; 7.7-8; SI 23.1; 78.71-72; Ez 34.1-31; Jo 10.1-18). [...] A imagem de pastor/rebanho é associada repetidamente a Davi e a Jesus (SI 23, 1Sm 17.15, 20, 28, 34, 40; 2Sm 5.2; 7.8; Ez 34.23) (BÍBLIA, 2011, p. 488).

Embora o texto bíblico mencione a responsabilidade dos pastores terrenos no cuidado com as "ovelhas" (BÍBLIA, 2011, Hebreus 13.17), é importante destacar que elas não são, e nunca serão, dele, mas, de Jesus, como Ele mesmo declarou a Pedro, ao convocá-lo a pastorear as suas "ovelhas" (BÍBLIA, 2011, João 21.16-17), pois, o governo, a supremacia e a autoridade pertencem unicamente a Deus. Ele os designa como cooperadores da sua Missão (BÍBLIA, 2011, 1 Coríntios 3.9, Mateus 16.18), 
afinal, Cristo é o cabeça da Igreja (BÍBLIA, 2011, Efésios 4.15) e usa a quem quer, como quer, seja homem ou mulher (BÍBLIA, 2011, 1 Coríntios 12.6-14).

Conforme acima mencionado, seguindo o conceito claro do termo "ordenar", "reconhecer o dom", negar esse reconhecimento do dom conferido a alguém pelo próprio Deus, significaria resistir à vontade de Deus (BÍBLIA, 2011, Atos 11.17-18). Sendo o ministério pastoral também compreendido como um dom concedido pelo Espírito Santo à Igreja de Cristo, é possível evidenciar que Deus, através do Espírito Santo, pode concedê-lo tanto aos homens quanto às mulheres para aquilo que lhe for útil (BÍBLIA, 2011, 1 Coríntios 12.7). Também em 1 Pedro 4.11, "a palavra 'realiza' vem do verbo grego energeo, que significa operar, trabalhar, produzir, efetuar" (CHAMPLIN, 1982, p. 193), ou seja, Deus é soberano e onisciente e não faz acepção de pessoas, mas atrai a todos, salva a todo aquele que Nele crê, por sua graça e amor (BÍBLIA, 2011, João 3.16-18), e capacita a quem Ele quer, para produzir o que the apraz.

O apóstolo Paulo diz, ao descrever os cristãos como cooperadores de Cristo: "O que possuímos que não tenhamos recebido de Deus? "Pois quem é que te faz sobressair? E que tens tu que não tenhas recebido, e se o recebeste, porque te vanglorias, como se o não tiveras recebido?" (BÍBLIA, 2011, 1 Coríntios 4.7), pois, havia alguns que se vangloriavam como se fossem detentores da Glória, que é de Deus. A respeito destes, Champlin (1982, p. 157) afirma que, ainda hoje, "alguns agem como se o que tem fosse produzido por eles". Após viver uma intensa experiência com Deus, Jó afirmou: "Bem sei que tudo podes e que nenhum dos seus planos pode ser impedido" (BÍBLIA, 2011, Jó 42.2). Logo, se tudo pertence a Deus e é para o louvor da sua Glória, Ele mesmo distribui seus dons para proveito da sua obra salvífica. Segundo A Bíblia da Mulher, "os dons espirituais [...] são divinamente concedidos, não para exaltar o indivíduo que os tem, mas para aumentar seus esforços no ministério. Dons são derramados sobre mulheres e homens, porém sem requisito de que todos os dons se encontrem em um ou outro sexo" (BÍBLIA, 2011, p. 1802), o que reafirma que Deus não faz distinção alguma ao distribuir os seus dons. 
Lima e Mello (2016) evidenciam em sua pesquisa, que existem casos em que há o reconhecimento do dom de Deus concedido à mulher, porém negando-lhe o título, o que é, no mínimo, incoerente. Há aqueles que preferem se referir a elas como "missionárias", ou até mesmo "doutoras", mas não "pastoras", por mais que detenham todas as qualificações para o exercício do ministério pastoral, inclusive, o mais importante, o chamado de Deus. Em contrapartida, há, também, muitos homens que ostentam o título sem jamais terem sido vocacionados ao pastorado, muitos destes, infelizmente, servindo de escárnio ao Evangelho. Em entrevista à revista Seara (que sucedeu "A Seara"), Nascimento (1998, p. 17), afirma: "[...] não obstante ter havido um avanço muito grande na igreja no que diz respeito ao trabalho da mulher, o preconceito ainda existe, principalmente no âmbito hierárquico. A mulher, mesmo líder, não tem a importância que um presbítero tem.". Em todo o caso, é importante destacar que todo cristão é servo de Cristo e despenseiro "dos mistérios de Deus" (BÍBLIA, 2011, 1 Coríntios 4.1), logo, a Glória, a autoridade e o domínio são, e sempre serão, exclusivamente de Deus.

\section{CONSIDERAÇÕES FINAIS}

De acordo com os elementos e fatos evidenciados na pesquisa, é possível concluir que, principalmente devido a influência da cultura e das tradições judaicas, e de outros povos, da época em que foram escritos os textos bíblicos, a preponderância da liderança na Bíblia era masculina. No entanto, mulheres revestidas pelo Espírito Santo, consagradas e escolhidas por Deus nunca foram impedidas de exercerem funções ministeriais e de liderança, nem no exercício de dons espirituais por Ele concedidos. É possível constatar que a dominação do marido sobre a esposa é bíblica (BÍBLIA, 2011, Gênesis 3.16), mas a de toda a classe masculina sobre a feminina, ou seja, de todos os homens de uma sociedade à todas as mulheres, é um sinal cultural. Deste modo, sobre a questão norteadora em relação à liderança eclesiástica por parte da mulher, esse artigo evidencia que a análise do papel da mulher no contexto bíblico, de fato, auxilia na aceitação da legitimidade do pastorado feminino na igreja evangélica da atualidade, uma vez que seria inadequado opor-se a estas inúmeras evidências Bíblicas, em nome de tradições eclesiásticas, para negar às mulheres a 
sua devida e Bíblica liberdade de expressão no exercício de suas atribuições ministeriais outorgadas pelo próprio Deus.

No entanto, na atualidade, ainda há muitos que, com as suas ideias pré-formadas não conseguem conceber ou assimilar o que lhes pareça contrário e, com isso, no que diz respeito às mulheres, tentam calar-Ihe a voz, coibindo que exerçam cargos de liderança eclesiástica, ainda que, com zelo, autoridade, ousadia, fé e amor, concedidos por Deus. Muitas mulheres tementes a Deus, virtuosas, piedosas, obedientes, servas do Altíssimo, cheias do Espírito Santo, comprometidas com o estudo das Escrituras Sagradas, com a oração e com o pastoreio das almas e que, também, possuem convicção do seu chamado ministerial como sendo da parte de Deus, tem sido rejeitadas, e, até mesmo, humilhadas, em seu exercício ministerial, pois muitos são contrários à presença feminina no púlpito das igrejas na função de pregadoras do Evangelho ou pastoras do rebanho de Cristo, por considerarem antibíblica e inadmissível a ideia de se submeterem à autoridade de uma líder feminina, mesmo com a não existência de uma autoridade bíblica para o estabelecimento destas regras, conforme mencionado na pesquisa.

Entretanto, é importante conscientizar-se de que os discípulos de Cristo são apenas cooperadores da Missão de Deus (BÍBLIA, 2011, 1 Coríntios 3.9) e que é Ele quem detém toda a autoridade (BÍBLIA, 2011, Efésios 4.15), para usar a quem quer, como quer, segundo a sua vontade (BÍBLIA, 2011, 1 Coríntios 12.11), para a edificação da sua Igreja. A pesquisa mostra que Deus capacitou e aprovou a liderança de Débora sobre o seu povo, não para dar uma "lição" nos homens que se acovardaram e negligenciaram o seu chamado, na época, e, sim, para demostrar, mais uma vez, que Ele é soberano e que distribui seus dons espirituais a quem quer, seja homem ou mulher (BíBLIA, 2011, Efésios 4.12-15; 1 Coríntios 12.6-14). Portanto, que, ao invés de apegar-se a elementos do contexto sociocultural em que vivia a Igreja na época em que os textos Bíblicos foram escritos, cada cristão possa crescer e se fortalecer em Deus, como parte integrante da Igreja do Altíssimo.

Assim, na atualidade conclama-se por mais homens de fé, guerreiros, corajosos, piedosos, pastores de almas e obedientes a Deus, como Paulo, Pedro e tantos outros, 
até os dias de hoje. Por mais mulheres destemidas, corajosas, fiéis a Deus, piedosas, obedientes, leais, pastoras de almas, como Débora, Miriã, Hulda e tantas outras, até os dias de hoje. A fim de que o propósito de Deus em levantar cooperadores para a sua missão dada à Igreja (BÍBLIA, 2011, Efésios 4.11-12) seja cumprido e a sua Igreja seja edificada, avivada e fortalecida, para a sua Glória, afinal, foi para este propósito que a humanidade foi por Ele criada, macho e fêmea, ambos com a mesma finalidade, o Louvor da sua Glória (BÍBLIA, 2011, Efésios 1.11-12). De modo que, juntos, os cristãos formam um só corpo em Cristo e são, individualmente, membros uns dos outros (BÍBLIA, 2011, Romanos 12.5), em outras palavras, é Cristo por todos e todos por Cristo, afinal há um só Deus, uma só missão (a Dele), uma só visão e um só alvo, Jesus. A Ele toda honra e Glória, pelos séculos dos séculos, Amém!

\section{REFERÊNCIAS}

ALLEN, Curtis. Como interpretar a Bíblia: princípios práticos para entender e aplicar a palavra de Deus. Tradução: Carlos Lopes. São Paulo: Vida Nova, 2012.

ALVES, Branca Moreira; PITANGUY, Jacqueline. O que é feminismo. São Paulo: Brasiliense, 1985. (Coleção Primeiros Passos).

BASKIN, Judith. Women in the Bible: changes in society affected attitudes toward women. Disponível em: https://www.myjewishlearning.com/article/women-in-thebible/. Acesso em: 13 mar. 2020.

BEAUVOIR, Simone. O segundo sexo. 2. ed. São Paulo: Difusão Europeia do Livro, 1970.

BÍBLIA. A Bíblia da Mulher. Leitura, devocional, estudo. 2. ed. Barueri, SP: Sociedade Bíblica do Brasil, 2011. 2176 p. Almeida Revista e Corrigida (ARC). (Português).

BIBLIATODO. Diário viver - comentário da Bíblia. Disponível em: https://www.bibliatodo.com/pt/comentarios-da-biblia/?v=PJFA\&co=diarioviver\&l=1+timoteo\&cap=2. Acesso em: 13 mar. 2020. 
BRASIL. Ministério da Economia. Secretaria de Políticas Públicas e Emprego. Mulheres ocupam 43,8\% dos cargos de chefia no país. 08 mar. 2019. Disponível em: https://www.gov.br/economia/pt-br/assuntos/noticias/2019/03/mulheres-ocupam43-8-dos-cargos-de-chefia-no-pais. Acesso em: 12 fev. 2020.

CHAMPLIN, Russell N. Comentário Bíblico do Novo Testamento: versículo por versículo. 3. ed. São Paulo: Milenium, 1982.

CUNDALL, Arthur E. Juízes. In: CUNDALL, Arthur E.; MORRIS, Leon. Juízes e Rute introdução e comentário. Tradução: Oswaldo Ramos. São Paulo, SP: Vida Nova, 1986.

JOSEFO, Flávio. História dos Hebreus: de Abraão à queda de Jerusalém. Tradução: Vicente Pedroso. 8. ed. Rio de Janeiro: Casa Publicadoras das Assembleias de Deus, 2004. (Obra Completa).

KELLER, Kathy. Jesus, justiça e papéis de gênero: mulheres no ministério. Tradução: João Guilherme Anjos. 1. ed. Rio de Janeiro: Thomas Nelson Brasil, 2019.

KOCHMANN, Sandra. O Lugar da Mulher no Judaísmo. Revista de Estudos da Religião, São Paulo, PUC-SP, n. 2, p. 35-45, 2005. Disponível em: https://www.pucsp.br/rever/rv2_2005/p_kochmann.pdf. Acesso em: 09 fev. 2020.

LIMA, Daniel Barros; MELLO, Adriana Girão da Silva. A mulher e os desafios na conquista do pastorado: Um estudo de caso em uma igreja evangélica Assembleia de Deus na cidade de Manaus. Coisas do Gênero, Revista de estudos feministas em gênero e religião. v. 2, n. 1. p. 119-134, Jan./Jul. 2016. Disponível em: http://www.est.com.br/periodicos/index.php/genero/article/view/2753. Acesso em: 10 fev. 2020.

LUCADO, Max. Dez mulheres da Bíblia: uma a uma elas mudaram o mundo. Tradução: Frank de Oliveira. 1. ed. Rio de Janeiro: Thomas Nelson Brasil, 2018. 
MACARTHUR, John. Doze Mulheres Extraordinariamente Comuns: como Deus moldou as mulheres da Bíblia e o que Ele quer fazer com você. Tradução: Maurício Bezerra Santos Silva. 1. ed. Rio de Janeiro: Thomas Nelson Brasil, 2019.

MERRIL, Eugene H. História de Israel no Antigo Testamento: o reino de sacerdotes que Deus colocou entre as nações. Tradução: Romell S. Carneiro. 3. ed. Rio de Janeiro: Casa Publicadoras das Assembleias de Deus, 1987.

NASCIMENTO, Cléia. Revista Seara, Rio de Janeiro, ano 41, n.16, mar. 1998.

PERROT, Michelle. Os excluídos da história: operários, mulheres e prisioneiros. 2. ed. Rio de Janeiro: Paz e Terra, 1992.

PFEIFFER, Charles F.; HARRISON, Everett F. Comentário Bíblico Moody: Josué a Cantares. v. 2. São Paulo, SP: Imprensa Batista Regular, 1985.

SHELDON, Charles M. Em seus passos o que faria Jesus? Tradução: Robinson Malkomes. São Paulo: Mundo Cristão, 2007.

SHPERBER, Daniel. Shlosha minhaguim mathimim, umekomam shel nashim beBeit Hakneset. In: SHILO, Margalit (org.). Lihiot Isha lehudia. Jerusalém: Ed. Urim, 2003. v. 2. p. 25-33.

TESSELER, Fani Averbuh. Vozes de mulheres: educação, universidade e trabalho nos anos 40 e 50 do Século XX. 2009. Tese. (Doutorado em Educação) - Universidade Federal do Rio Grande do Sul. Porto Alegre, 2009. Disponível em: http://www.lume.ufrgs.br/bitstream/handle/10183/18381/000729544.pdf?sequence=1 . Acesso em: 20 mar. 2020.

TUPAN JÚNIOR, Galaor Linhares. Modelos de plantação de igrejas. Maringá, PR: Unicesumar, 2017.

VAUX, Roland de. Instituições de Israel no Antigo Testamento. São Paulo: Vida Nova, 2004. 
WRIGHT, Nicholas Thomas. Paulo para todos: cartas pastorais. 1, 2 Timóteo e Tito. Tradução: Hilton Figueredo. Rio de Janeiro: Thomas Nelson Brasil, 2020.

\section{APÊNDICE - REFERÊNCIA DE NOTA DE RODAPÉ}

3. "Rabina Sandra Kochmann, é formada pelo Seminário Rabínico Latino-americano 'Marshall T. Meyer' do Movimento Conservador, na Argentina, e em Organização e Direção de Instituições sem Fins Lucrativos, pela Universidade Hebrea-Argentina Barllán. Participou no Programa 'Melton' de Capacitação de Professores judeus da Diáspora na Universidade Hebraica de Jerusalém; desde setembro de 2003 é Rabina da Associação Religiosa Israelita do Rio de Janeiro (ARI), sendo a primeira mulher em desempenhar esta tarefa no Brasil” (KOCHMANN, 2005, p. 35).

Enviado: Novembro, 2021.

Aprovado: Dezembro, 2021. 